\title{
$\mathrm{KTa}_{x} \mathrm{Nb}_{(1-x)} \mathrm{O}_{3}$ 及び $\mathrm{Ba}_{2} \mathrm{NaNb}_{5} \mathrm{O}_{15}$ に於ける相転移と双晶
}

Phase Transition and Twinning of $\mathrm{KTa}_{x} \mathrm{Nb}_{(1-x)} \mathrm{O}_{3}$ and $\mathrm{Ba}_{2} \mathrm{NaNb}_{5} \mathrm{O}_{15}$

高須 新一郎 (Shinichiro Takasu)*

福田承生 (Tsuguo Fukuda)*

武居 文 彦 (Fumihiko Takei)*

$\mathrm{KTa}_{x} \mathrm{Nb}_{(1-x)} \mathrm{O}_{3}(\mathrm{KTN})$ 及ご $\mathrm{Ba}_{2} \mathrm{NaNb}_{5} \mathrm{O}_{15}(\mathrm{BNN})$ は, 上もに光電子工学用材料さし て，最近注目さ机ている強誘電体結晶である ${ }^{122) 3}$ 。 KTN は $x$ によって転移点が変化 し， $x=0.6$ 附近で室滥附近で転移し，高温怆は等軸晶系常唀電体で，低温相は正方 晡系強誘電体である。 $\mathrm{BNN}$ は第 10 転移点が約 $560^{\circ} \mathrm{C}$ 附近にあり, 常誘電体から強

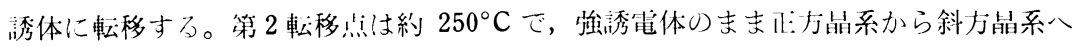
転移する。KTN はへロブスカイト形構造，BNN はタングステンブロンズ形構造在 上万。

㞹者の笚結旨は通常次の方法で方成さ机る。

$\mathrm{KTN}$ : 過剩の $\mathrm{K}_{2} \mathrm{CO}_{3}$ 在加えた $\mathrm{Ta}_{2} \mathrm{O}_{5}$ 上 $\mathrm{Nb}_{2} \mathrm{O}_{5}$ 在允分沚へし，け企ルツポ在月小

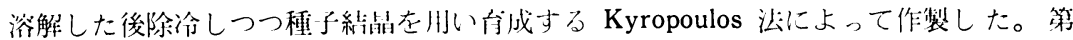
1 汹に示めす梯に $\mathrm{KTN}$ は， $\mathrm{KNbO}_{3}-\mathrm{KTaO}_{3}$ 系に属するために，垷実の晶出条件で は初期旨出相上後期晶出相10差を完全になくする事は怵難である。又温度引上速度等 の引上げ条件の変動により成分変動も惹き起されてる(2)576)7)。BNN : 所定化学量論比の $\mathrm{BaCO}_{3}, \mathrm{Na}_{2} \mathrm{CO}_{3}, \mathrm{Nb}_{2} \mathrm{O}_{5}$ を混合仮焼したものをけ金ルツボに入机熱溶解せしわ，種 子結晶を用い引き上げるチョクラルスキ法によって有成した。KTN ほよ゙ではないが， 引き上げ中の温度の変動等の原因により必ずしも一定の成分のものが育成されるこは 限らな( ${ }^{6) 7) 8) 。 ~}$

観察用試料は，KTNでは育成結晶そのままの成長軸に対し平行な側面を，BNN 結 晶では， $c$ 軸引き上げ結晶からC 面板在切断製作して使用した。温度変化は第 2 四に

* 東芝総合研究所 


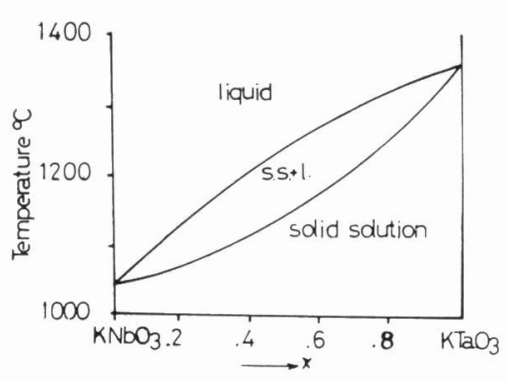

第 1 威 $\mathrm{KNbO}_{3}-\mathrm{KTaO}_{3}$ 状態汹

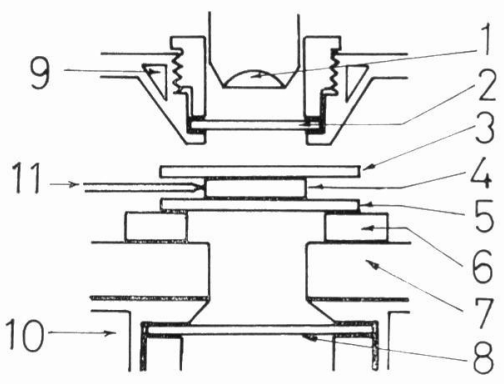

第2図式料 0 打䓡

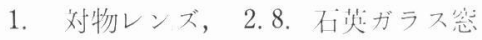

3.5. 均熱师不点板

4. 试料, 6. 断熱材 7. ヒーター ブロック 9.10. ウォータージャ

ケット, 11. 熱電刘

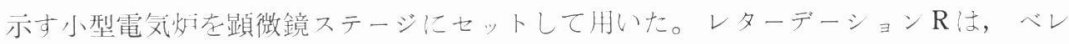
ク型コンヘンセータにより，双晶数は引き伸した真上で測定した。映画はアリフレ

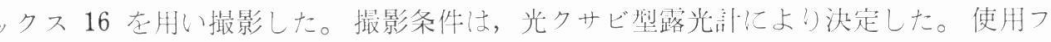

1

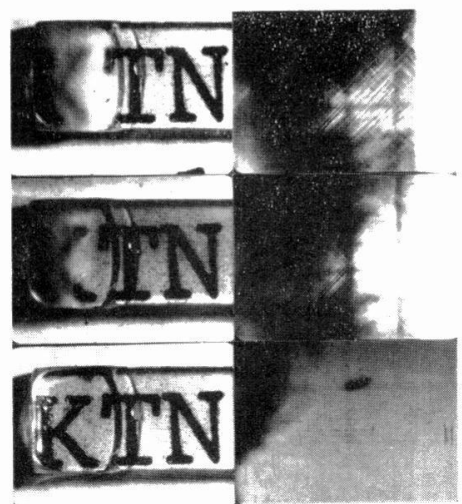

$0 \begin{array}{llll}0 & 2 & 3\end{array}$

$0 \cdot 1 \cdot 2 \cdot 3 \cdot 4$
3

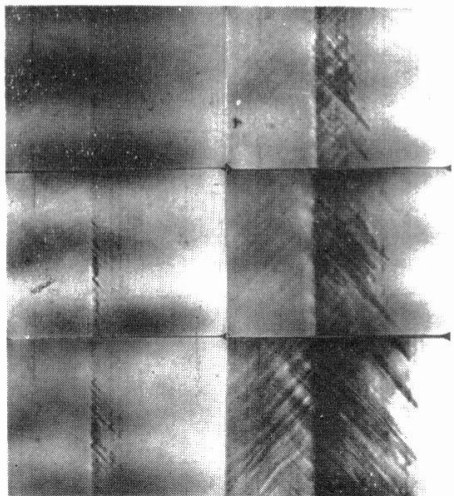

$0.0 .1 \quad 0.2$

与真 1 KTN 集片双晶の温度変化 $(16 \mathrm{~mm}$ シネより)

1. 昇温に上る白摆の消失 2 . 个渴消失侍の双晶の消滅

3. 温度降下時に於ける双晶の発生 


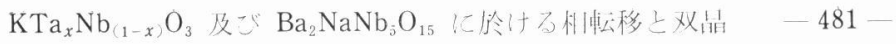

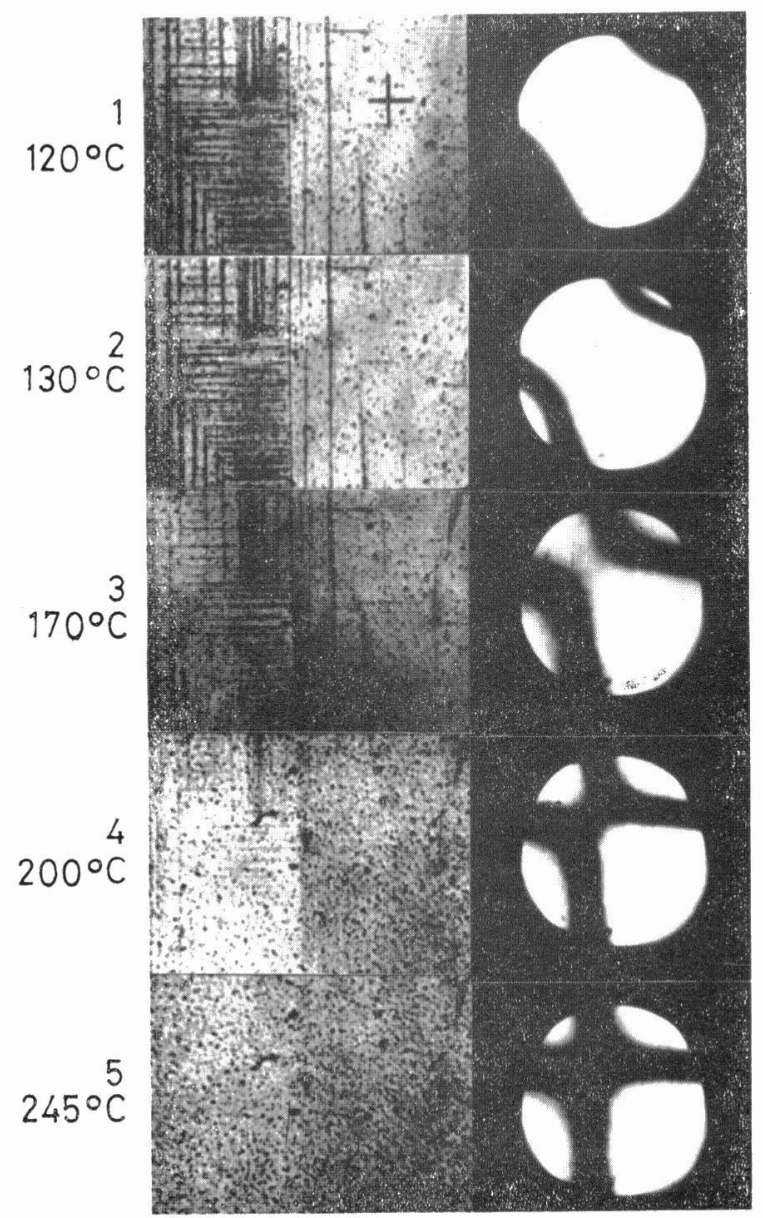

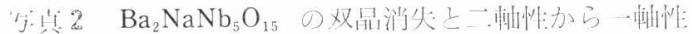
人の枟移の関係 $(16 \mathrm{~mm}$ シネより)

No. $10 \div$ 詂近でコ, スコープ観察

ィルムは，コダック社トライ X, 同カラーネガ, 富上リバーサル $\mathrm{R}-40$, 同 $\mathrm{R}-250$ 在 条件, 目的により使い分けた。拡大撮影にはアダプタ走作り, 東京光学マイクロレン ズ及びライツュニバーサルステーズ用レンズを使用した。

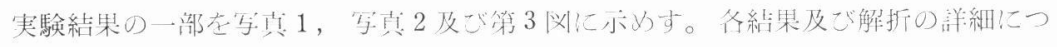
いては別途報告にゆずり,ここではそのまとりたものについてのべる。 


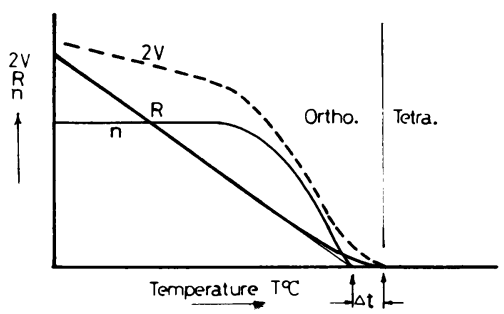

第 3 図 BNN の光軸出 $(2 \mathrm{~V})$ ，レターデーション $(\mathbf{R})$, 双晶数 $(\mathrm{n})$ と滥度の関係

\section{KTN の場 合 ${ }^{12}$}

1. KTN の転移に伴なう白濁とその消失は，転移に伴なう集片双旨の発生と消失に より説明出来る。

2. 双晶の大きさは，結晶の成長条件により恭なる。今結脂の成長方向に $x$ をとり, その方向に沿った $T_{c}$ の変化を測定し,

$$
\kappa=\Delta T_{c} / \Delta x
$$

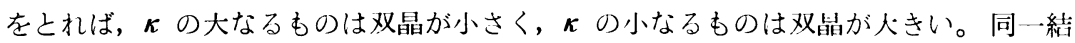
旵内でも同様な結果が得られた。

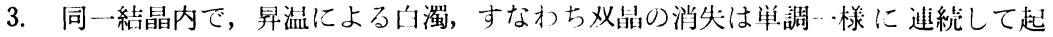
らない結旨が多い。

4. 双晶の発生及び消失する湖所は略々一定している。種々の点から考えて, この 個所は, $\mathrm{KTa}_{x} \mathrm{Nb}_{(1-x)} \mathrm{O}_{3}$ の $x$ の変化の大なる点であろう。したがって，二の様な点 では compositional stress が大である上思打扎 ${ }^{13)}$ 。

5. 転移後双脂数は温度の低下に従がい増加するが，ある温度より下ではこの增加 は起らない。

\section{BNN の 場 合}

1. BNN に対しても，KTN 上ほほ同様な転移上双晶の関係が見ら机る。

2. $2 \mathrm{~V}, \mathrm{R}$ ，双旨数は温度の一価函数である。第 3 汹参照。

3. 双晶が発生すると,アイソヂ+イヤーに筫常が観測される。

4. 双晶の発生は, 光学的な測定, たとえば $2 \mathrm{~V}$ の変化, $\mathrm{R}$ の变化より得られる転 移点より約 $10^{\circ} \mathrm{C}$ 程度下で起る。

5. 場所により双晶境界，形状，双晶密度が坚なる。

6. 低温相から高温相に転移した後， $20 \sim 50^{\circ} \mathrm{C}$ の間，大きな領域の僅かな光学的 
な差異が認められる個所がある。この領域は低温相ではなく，高温相の光学的性質を 示めす。KTN でも同様である。

BNN 数似の結晶に対する観測, 測定むほぼ同様な結果が得られた。従がってKTN, BNN 及びその類似の結鼠に対し次の様にいえる。

1. 電界並びに外力等が加わっていない状態では, 上記の如き結晶は, 双晶の発生 消失点も含め, 相転移はほぼ可逆的に起る。

2. 相転移に伴なう双晶は, 光学的に認めら机る転移点の $5 \sim 10^{\circ} \mathrm{C}$ 下で発生す る。転移点附近に於ける格子常数変化が極めて小さい事などを考え合わせると，ての 類縁の結晶に対する転移に伴なう双晶は, 転移後双晶発生迄の温度差による昰の集積， を打消す為に発生すると考えられる。

3. 成分変化の大なる所では, 高温相から低温相に転移した後に発生する歪に,

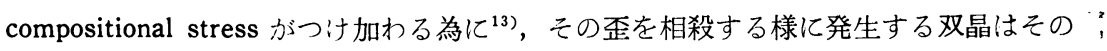
数が多く, 転移後双晶発生までの温度差が小さくなる。とのように考えると種々の現 象を説明出来了。

以上の点は, 否の解析, 格子常数の変化等まだ種々の研究方法により確認され杖ば ならない点が多々あるが, 転移点附近の連続的な拡大観察が相転移, 双晶発生に対し かなりの寄与をなし得る例として報告した次第である。

\section{文献}

1）新関暢一：日本結晶学会誌 9,28(1967)

2) 1 応用物理 38, 812 (1969)

3）小出重直外：東芝レビュ-24, 1516 (1969)

4) R. L. Barns : Mat. Res. Bull. 2, 273 (1967)

5) S. A. Levy \& R. Gashler : Mat. Res. Bull. 3, 417 (1968)

6) 平野, 福田, 小出：応用物理 38, 928 (1969)

7) 福田, 小出, 平野: 応用物理 38, 995 (1969)

8) A. C. Pastor, R. C. Pastor \& B. H. Soffer : Mat. Res. Bull. 1, 205 (1966)

9）武居，高須，第12回人工鉱物討論会（東京）（1967）

10) L. G. van Uitert, H. J. Levinstein, J. J. Rubin, C. O. Capio, E. F. Dearborn \& W. A. Bonner : Mat. Res. Bull. 3, 47 (1968)

11) R. R. Zupp, J. W. Nielsen \& P. U. Vittorio : J. Cryst. Growth, 5, 269 (1969)

12) 高須, 福田：第13回人工鉱物討論会（東京）（1968）

13) W. R. Wilcox : Mat. Res. Bull. 2, 121 (1967) 